Paper submitted for publishing in The Economics of Transition, June 2004

Project: "Tax Evasion, Underground Economy and Fiscal Policies in Candidate

Countries (Case of Romania)" (GRC III-100, 2003)

\title{
Estimating the Size of Underground Economy in Romania*
}

\author{
Lucian-Liviu Albu \\ (Institute for Economic Forecasting)
}

* Correspond to: L-L Albu, Institute for Economic Forecasting, Romanian Academy, Casa Academiei, Calea 13 Septembrie, No. 13, Sector 5, 050711 Bucharest, Romania; tel./fax: +40-021-4119392; e-mail: lucianl@,rnc.ro,ipe@,ipe.ro, liviul@hotmail.com.

This research was supported by a grant from the CERGE-EI Foundation under a program of the Global Development Network. Additional funds for grantees in the Balkan countries have been provided by the Austrian Government through WIIW, Vienna. It was prepared as a part of the FINAL REPORT for the research project "Tax Evasion, Underground Economy and Fiscal Policies in Candidate Countries" (GRC III-100, 2003); partners: Lucian-Liviu Albu (coordinator), Mariana Nicolae, Mihaela-Nona Chilian, and Carmen Uzlau from Institute for Economic Forecasting, Aurel Iancu from Romanian Academy (Academician), Clementina Ivan-Ungureanu from National Institute of Statistics (President) and Institute for Economic Forecasting, and as external collaborator from EU Byung Yeong Kim (Essex University). All opinions expressed are those of the authors and have not been endorsed by CERGE-EI, WIIW, or the GDN. The authors thank to Mr. Edward Christie, from WIIW, for scientific support and for supplying all the time useful observations, suggestions, and solutions. 


\begin{abstract}
Based on two Romanian household surveys, we analyse the structure of households' income by sources: main job, secondary job, and hidden activities. After conceptual clarification and explanation of the methodology we used, we estimate the size of informal economy, analyse the relationship between variables related to different types of income, and explore the dynamics of the informal economy. We find that the main participants in the informal economy are the poor people: the survival motive is dominant in the Romanian informal economy. We estimate that both in September 1996 and in July 2003 the income from the informal economy amounted to about $1 / 4$ of the total household income (23.6\% in 1996 and $22.7 \%$ in 2003, respectively). Also, we estimate the share of income from the informal economy in the cases of various categories of population (defined according to the dimension of the official declared income per person in the household). The extension of our analysis to the entire year using the household population structure by deciles suggests that the informal economy has increased, on average, by about 2$2.5 \%$ over the period $1995-2002$.

Indeed, beside the actual level of income, the households' involvement in informal activities is probably influenced by occupation, region, age, education, number of children and many other factors. However, certain conclusions could be outlined:

- People perceive taxation as the main cause of the underground economy.

- Separating the main motivations of operating in the informal sector in two groups, "subsistence" and "enterprise" respectively, the surveys suggest that the subsistence represented a relevant reason for the households' decision to operate in the informal economy, including its underground segment.

- Informal activities supplied a "safety valve" within the surviving strategies adopted by the poorest households.

- Participation in informal economy seems to be not simply correlated with poverty: in the informal economy are involved poor people (having probably a low educational level), as well as rich persons, but their motivations are quite different. The former are practically "forced" to operate in the informal economy (the "subsistence" criterion), but the latter are "invited" to participate in it (the "enterprise" criterion). In both cases, at least during the first stages of transition to a free market system in Romania, the environment was propitious due to legislative incoherence, feeble penalty system in the cases of fraudulent activities, and existence of some accompanying elements of proper informal activity, such as corruption, bureaucracy, etc. However, the household's behaviour related to the participation in informal economy is sometimes fundamentally different between the two extreme groups of population. This is why in this study we focused on a deeper investigation of the behavioural aspects of different groups of population related to the implication in the informal sector.
\end{abstract}

JEL Classification: C61, D10, E62, H31, J22, O17, P36

Key Words: Informal Economy, Secondary Income, Informal Income, Decent Income 


\section{Introduction}

After 1989, the size of the underground economy in Romania has been an issue of concern to the policy makers. Recent evidence suggests that the problem is especially serious today, taking also into account the efforts needed in order to prepare Romania's accession into EU at the beginning of 2007. Among the most important "dossiers" of negotiations with EU are those of "combating tax evasion and avoidance" and "reform of fiscal system and fiscal policy". In this context, many problems emerge, since it is widely believed that high tax rates and ineffective tax collection by the government are the main causes contributing to the rise in the underground economy. The economists have already established a relationship between tax rates and the amount of tax evasion or the size of the underground economy: the higher the level of taxation, the greater the incentive to participate in underground economic activities and escape taxes.

At the macroeconomic level there are several so-called indirect methods used to estimate the size and dynamics of the underground economy, reported in literature as "Monetary Approach", "Implicit Labour Supply Method", "National Accountancy", "Energy Consumption Method", etc. Unfortunately, many times there are large differences among the estimated shares of informal or underground economy obtained by various methods. For instance, in the case of Romania the figures range between about $20 \%$ of GDP, obtained on the basis of the energy consumption method (Enste and Schneider, 2000) and more than $45 \%$ computed using the monetary approach (French, Balaita, and Ticsa, 1999). Also, the figures (based on the national accounts methodology) reported by the National Institute for Statistics (NIS) increased (mainly due to changes in methodology); from about 5\% in 1992, to $18 \%$ in 1997 and to $20-21 \%$ in 2000-2001. Adding to these figures about 7\% of GDP, representing the estimated average level of self-consumption in the case of a rural household, legally non-registered but informal, it results that during the last years the informal economy accounted for 25$28 \%$ of the national economy.

When the economists study the underground economy, its determinants and mechanisms, the use of the econometric analyses is obviously limited. The main problem is to estimate simultaneously its size and its factors. In this case, to establish correctly the basic hypotheses of the model and, consequently, the variation interval for the state or slow variables will be decisive. Sometimes, in order to avoid this impediment and to build the econometric model in a classical way, some authors consider the size (or the share) of the real underground economy as known, by using data reported in other studies. Then, ignoring the original model (deterministic one, as a rule) used to estimate the size of the underground economy in those studies and its hypotheses, they independently estimate their own econometric model in order to analyse the relationship between various determining factors and the dynamics of the underground sector. In our opinion this procedure is not very accurate, mainly because the input data for the size (or dynamics) of the underground sector are in fact outputs of the models in the studies used as sources. It is sometimes possible that the conclusions obtained as a result of such a way of using the econometric models contradict the basic deterministic model used to produce data for the size of the underground sector. More concretely, the same factors already used in a deterministic way to obtain estimates of the size of the underground sector (in the case of the original studies used as sources of data) could be used as determinants, but this time under a very different mechanism imposed by a specific econometric model. 
Also, in the case of surveys, to ask directly how much is a person or household involved in underground activities has no chance to obtain an accurate answer (only certain indirectly formulated questions in special conditions might have a chance to capture the size of people's implication in underground activities, as it will be shown in this paper).

One goal of the paper is to report some conclusions of our investigation based on the data supplied by special surveys organised in Romania. In order to see if certain hypotheses (referring to the complex transmission mechanism from the tax policy decisions to the effective implication of agents into underground economy) are statistically verified and to extend the study from the aggregate level to a deeper research inside the population set, we used data supplied by a special large survey organised in Romania in September 1996, which already were processed and are available in our database. Also, in order to study the changes over time in the households' behaviour we used data collected by a specialised Romanian institution that organised (under the logistic coordination of the National Institute for Statistics and us) a smaller survey in July 2003, based on a kernel-sample of about 300 households and using a reduced survey form of that used in September 1996. The sample was forced to cover reasonably at national level all the income groups of population, in order to capture a realistic imagine of the changing trend of the people's behaviour relative to the participation in underground activities when their official or formal income was growing from the poorest level to the richest level during the last years.

\section{Considerations on data and methodological aspects}

Broadly speaking, three groups of methods are used in order to estimate the size of informal economy: time-series analysis based on cash demand; estimates based on the discrepancy between total incomes and total expenditures at aggregate level; discrepancies between income and expenditure at the microeconomic level (Smith, 1986, Thomas 1992). Among them, Smith (1986) points out that the overall accuracy of the national accounts method is lower than the other two due to the inclusion of various errors in both the income and expenditure measures of GDP. The lack of reliable historical data before transition and the possible structural break between pre and post transition intervals suggest that the time-series method is not feasible to a large extent. The only remaining alternative is, therefore, to analyse the individual household data. Furthermore, the results of the analysis performed on the basis of micro-data might provide more significant information for policy-making because they, unlike those using aggregate data, can highlight the main participants in the informal economy and the effects on welfare/behaviour of the households.

The so-called Integrated Household Survey (IHS) is a survey that allows collecting information on households' composition, income, expenditure and consumption, as well as other aspects of the population living standard. The survey is carried out on the basis of a rotational sample in monthly equal waves, covering in one year the households of about 36000 dwellings in about 500 urban and rural research areas. It provides the main source of information for the study of the households' behaviour. Also, in September 1996 it was added to the rotational sample a Supplementary Survey on Household Informal Economy (SSHIE). The Supplementary Survey, using the same September sample of around 2600 households, was focused on informal economy activities carried out by households (Duchene et al., 1998). The survey was divided into 21 sub-sections comprising detailed questions - but indirectly formulated by answering means - about 
informal economy. In the case of the 1996 survey essential for our work was to correlate the two data sources (IHS and SSHIE, respectively).

Also, in July 2003, with the supporting funds from the GDN project, we tried to organise a similar survey. Unfortunately, we were forced to restrict our investigation only to a sample including around 300 households. Other impediment of the 2003 survey was referring to the impossibility to compare for the same household in the sample at least two distinct sources of data about its actual income, as it was the case in the 1996 sample (IHS and SSHIE, respectively).

The surveys asked about the ratio of the income from the main activity to that from the secondary activity. Using such information we obtained an absolute measure of households' income from the secondary activity. Based on answers provided by the question in which all members of household compared their two incomes (from main activity or from official awarded rights, in the case of unemployed, retired or other special categories of persons, and from declared secondary activities, respectively), we estimated a composite coefficient $(\mathrm{k})$ for every household in the sample, in order to characterise their shares in the total declared income. So, firstly we expressed the definition formula for $\mathrm{k}$ as follows:

$\mathrm{k}=\mathrm{X} / \mathrm{Y}$

where $\mathrm{Y}$ is the income from the secondary activity, $\mathrm{X}$ - the income from the main or basic activity, and $\mathrm{k}$ - the ratio between the two types of income. Then, knowing only the value of the total actual declared income, $\mathrm{V}$, the income corresponding to the main activity and to the secondary activities, respectively, can be written:

$\mathrm{X}=\mathrm{V} \cdot \mathrm{k} /(1+\mathrm{k})$

$\mathrm{Y}=\mathrm{V} /(1+\mathrm{k})$

Using (2) and (3), we can now express the shares of the two components in the total declared income of a household by the following computing relations:

$\mathrm{kb}=\mathrm{k} /(1+\mathrm{k})$

$\mathrm{ks}=1 /(1+\mathrm{k})$

One important result was also obtained by comparing the so-called decent (or desired) income with the actual size of total declared income. Thus, in order to capture the size of the potential underground economy (or better called hidden or informal economy in the case of household) we computed the following difference:

$\mathrm{ZD}=\mathrm{VD}-\mathrm{V}$

where ZD is the maximum level of desired hidden (informal) income, VD is the decent income (or the maximum level of the desired income), and the actual total declared income, $\mathrm{V}$, is equal to $\mathrm{X}+\mathrm{Y}$.

In order to ensure the comparability of data we firstly deflated by CPI the income level in July 2003. The computed outputs obtained from the two available surveys, by grouping data according to the ratio of the actual declared income to the desired income (see Appendix 1) in September 1996 and in July 2003, respectively, are synthetically 
presented in Table 1 . The last column in this table could be interpreted only as a potential (maximum) level of informal income. For instance, in the case of the households considering their actual level of income less than a "decent" (and indeed desired) level, the potential implication in informal activities could rise to shares of their desired income amounting to $62.9 \%$ in September 1996 and 58.7\% in July 2003. In fact, this "potential informal income", showing the "potential supply" of informal work desired by households, is probably covered only partially on the demand-side of the effective informal market. More plausible seem to be shares between $20.1 \%$ (in the case of the sample S380 comprising all households reporting $V \geq V D$ in the survey in 1996) and $26.2 \%$ (in the case of the sub-sample S288 comprising only the households reporting $\mathrm{V}=\mathrm{VD}$ in the survey in 1996), as can be computed on the data in Table 1. Moreover, in the case of households included in the sample S380 the information can be considered as reflecting the real situation. In the case of sub-sample S288, the last column of the table means the effective level of non-declared income - the informal or hidden income (computed by comparing for each household in S288 its official income reported in IHS and the level claimed as decent (desired) income in SSHIE, respectively, followed by the assertion that it equals the household's actual income). Also, we can consider data in the case of sub-sample S92 (households reporting their actual income as being larger than their desired income, V $>$ VD) as reflecting the real situation. Indeed, in this case there is no effective informal income and, consequently, the computed potential informal income is negative. Unfortunately, in a large number of cases (households reporting unsatisfactory ratio of their actual income to the minimum level of their desired income) it was no possibility in surveys to estimate how much of their supplementary desired income is effectively carried out. To discover the real dimension of this proportion in the case of the poorest group $(\mathrm{V}<\mathrm{VD})$ continues to be a challenge for economists and statisticians everywhere in the world.

Table 1. Households' income grouped by ratio of $V$ to VD, in 1996 and 2003

- thou Lei/person -

\begin{tabular}{|c|c|c|c|c|c|}
\hline & \multirow[b]{2}{*}{$\begin{array}{l}\text { Number of } \\
\text { households }\end{array}$} & \multicolumn{2}{|c|}{ Reported income } & \multirow{2}{*}{$\begin{array}{c}\text { Desired } \\
\text { income } \\
\text { vD }\end{array}$} & \multirow{2}{*}{$\begin{array}{c}\text { Potential } \\
\text { informal income } \\
z D=v D-(x+y)\end{array}$} \\
\hline & & $\begin{array}{l}\text { Main activity } \\
\mathrm{x}\end{array}$ & $\begin{array}{l}\text { Secondary activity } \\
\mathrm{y}\end{array}$ & & \\
\hline 1996 sample & 2561 & 146.6 & 12.6 & 367.7 & 208.5 \\
\hline $\mathrm{V}<\mathrm{VD}$ & 2181 & 127.0 & 9.8 & 368.2 & 231.5 \\
\hline $\mathrm{V}=\mathrm{VD}$ & 288 & 263.6 & 20.1 & 384.3 & 100.6 \\
\hline $\mathrm{V}>\mathrm{VD}$ & 92 & 258.0 & 53.8 & 201.8 & -110.0 \\
\hline 2003 sample & 300 & 141.2 & 10.8 & 358.6 & 206.6 \\
\hline $\mathrm{V}<\mathrm{VD}$ & 294 & 138.1 & 10.0 & 359.1 & 211.0 \\
\hline $\mathrm{V}=\mathrm{VD}$ & - & - & - & - & - \\
\hline $\mathrm{V}>\mathrm{VD}$ & 6 & 328.9 & 56.4 & 322.3 & -63.1 \\
\hline
\end{tabular}

Note: in the cases of sub-samples in which households are reporting $\mathrm{V}=\mathrm{VD}$ the difference $\mathrm{ZD}=\mathrm{VD}-(\mathrm{X}+\mathrm{Y})$ means the effective hidden informal income and for the sub-samples $\mathrm{V}>\mathrm{VD}$ the effective informal income is zero.

Figure 1 shows the general 3-D graphical distribution-map of the three main components of the total income of households $(X, Y, Z)$ in the case of the 288-sample. It suggests the existence of certain complex inverse correlations between $\mathrm{Y}$ and $\mathrm{X}$ and between $\mathrm{Z}$ and $\mathrm{X}$, respectively. In the next section, we shall analyse in more detail the relationships between the components of the total income, by using linear and hyperbolic descriptive functions. 


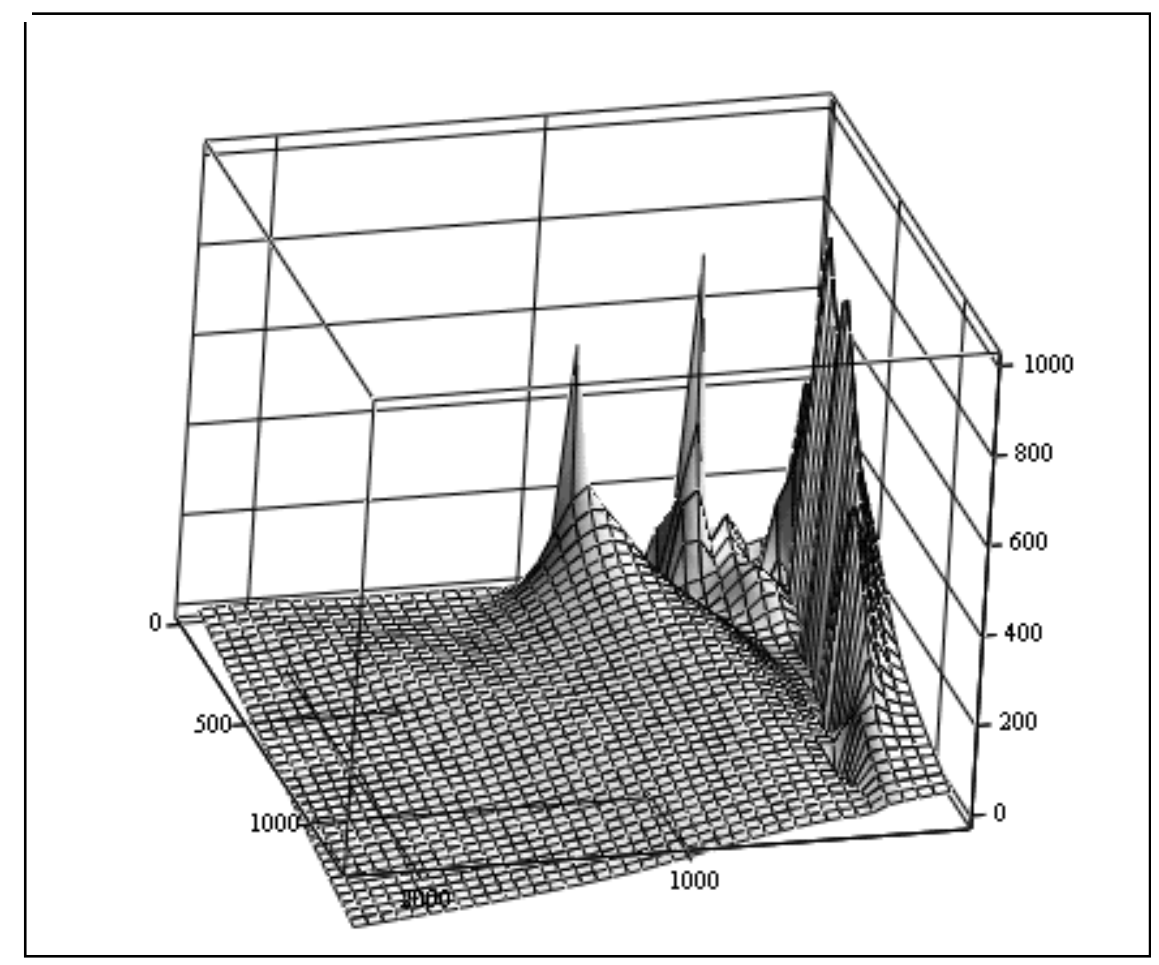

$(\mathrm{X}, \mathrm{Y}, \mathrm{Z})$

Figure 1.

\section{Regimes related to the households' demand for informal income}

A first rule derived from the data in Table 1 is to expect to find in the informal sector more poor households (households reporting $\mathrm{V}<\mathrm{VD}$ ). However, the households could also obtain additional income firstly from the formal secondary activities. That is why we consider useful to firstly investigate the proportion of their implication in officially registered secondary jobs.

Considering only two sources of the official registered income of households, we grouped them in: 1) households reporting secondary income and 2) households reporting no secondary income. As one may see from the data in Table 2, indeed the poorest households could be found in the first group. Despite that their poverty is ameliorated by adding income from secondary jobs (28.1 thousand Lei/person $=24.8 \%$ of the formal income in September 1996 and 31.5 thousand Lei/person $=22.3 \%$ of the formal income in July 2003, respectively), the formal income $(\mathrm{V}=\mathrm{X}+\mathrm{Y}$ or $\mathrm{v}=\mathrm{x}+\mathrm{y}$ in the case of expressing it by average level per person in household) continues to be below the level registered in the case of the group reporting no secondary activity.

Based on the available data, we used firstly some hyperbolic-type functions in order to estimate the share of the secondary income in the total reported formal income and the share of the desired informal income in the total desired income, respectively, as follows:

$$
\begin{aligned}
& \text { ye } \%(x)=a 1 /(x+b 1)+(1-a 1 / b 1) \\
& z D e \%(v)=a 2 /(v+b 2)+(1-a 2 / b 2)
\end{aligned}
$$


where $\mathrm{x}$ is the average basic income (officially registered) per person in household; $\mathrm{y}$ the average secondary income (also reported) per person in household; $v$ - the average formal income $(\mathrm{v}=\mathrm{x}+\mathrm{y})$ per person in household; $\mathrm{ye} \%(\mathrm{x})$ - the theoretic share of secondary income in $\mathrm{v} ; \mathrm{zDe} \%(\mathrm{v})$ - the theoretic share of potential (or desired) informal income in $\mathrm{vD}(\mathrm{vD}=\mathrm{VD} /$ number of persons in household); $\mathrm{a} 1, \mathrm{~b} 1, \mathrm{a} 2, \mathrm{~b} 2$ are coefficients to be estimated by the regression process. In order to build the two theoretical estimation functions, we used as basic hypotheses: $\mathrm{ye} \%(0)=1$ and $\mathrm{ye} \%(+\infty)=\mathrm{c} 1=(1-\mathrm{a} 1 / \mathrm{b} 1)$; $\mathrm{zDe} \%(0)=1$ and $\mathrm{zDe} \%(+\infty)=\mathrm{c} 2=(1-\mathrm{a} 2 / \mathrm{b} 2)$. Then, using some elementary algebraic operations implicitly resulted the following indirect four estimation equations for the variables $\mathrm{y}, \mathrm{zD}, \mathrm{v}$, and vD:

$$
\begin{aligned}
& \mathrm{ye}(\mathrm{x})=[(\mathrm{b} 1-\mathrm{a} 1) / \mathrm{a} 1] \cdot \mathrm{x}+\left(\mathrm{b} 1^{2} / \mathrm{a} 1\right), \text { with } \mathrm{ye}(0)=\left(\mathrm{b} 1^{2} / \mathrm{a} 1\right) \\
& \mathrm{zDe}(\mathrm{v})=[(\mathrm{b} 2-\mathrm{a} 2) / \mathrm{a} 2] \cdot \mathrm{v}+\left(\mathrm{b} 2^{2} / \mathrm{a} 2\right), \text { with } \mathrm{zDe}(0)=\left(\mathrm{b} 2^{2} / \mathrm{a} 2\right)
\end{aligned}
$$

and, respectively

$$
\begin{aligned}
& \mathrm{ve}(\mathrm{x})=(\mathrm{b} 1 \cdot \mathrm{x} / \mathrm{a} 1)+\left(\mathrm{b} 1^{2} / \mathrm{a} 1\right), \text { with } \mathrm{ve}(0)=\left(\mathrm{b} 1^{2} / \mathrm{a} 1\right) \\
& \operatorname{vDe}(\mathrm{v})=(\mathrm{b} 2 \cdot \mathrm{v} / \mathrm{a} 2)+\left(\mathrm{b} 2^{2} / \mathrm{a} 2\right), \text { with } \mathrm{zDe}(0)=\left(\mathrm{b} 2^{2} / \mathrm{a} 2\right)
\end{aligned}
$$

\begin{tabular}{|c|c|c|c|c|c|}
\hline & \multirow[b]{2}{*}{$\begin{array}{l}\text { Number of } \\
\text { households }\end{array}$} & \multicolumn{2}{|c|}{ Reported income } & \multirow{2}{*}{$\begin{array}{l}\text { Desired } \\
\text { income } \\
\text { VD }\end{array}$} & \multirow{2}{*}{$\begin{array}{c}\text { Potential } \\
\text { informal income } \\
\mathrm{ZD}=\mathrm{VD}-(\mathrm{X}+\mathrm{Y})\end{array}$} \\
\hline & & $\begin{array}{c}\text { Main activity } \\
\text { X }\end{array}$ & $\begin{array}{c}\text { Secondary activity } \\
\text { Y }\end{array}$ & & \\
\hline 1996 sample & 2181 & 127.0 & 9.8 & 368.2 & 231.5 \\
\hline $\mathrm{SI}(\mathrm{Y}=0)$ & 1406 & 149.2 & 0.0 & 388.5 & 239.2 \\
\hline SII $(Y>0)$ & 775 & 85.4 & 28.1 & 330.5 & 217.0 \\
\hline 2003 sample & 294 & 138.1 & 10.0 & 359.1 & 211.0 \\
\hline $\mathrm{SI}(\mathrm{Y}=0)$ & 209 & 151.4 & 0.0 & 359.1 & 213.8 \\
\hline SII $(Y>0)$ & 85 & 109.8 & 31.5 & 346.3 & 205.0 \\
\hline
\end{tabular}

Table 2. Average income in the case of households reporting $V<V D$, in 1996 and 2003

- thou Lei/person -

SI - households operating only in one activity (main or basic activity, according to the definitions included in the SSHIE questionnaire in September 1996 and in the survey in July 2003).

SII - households operating in more than one activity (main activity and secondary activities, according to the same definitions).

Taking into account the economic significance of the data in surveys and trying to obtain robust estimators, we selected two different ways of estimating the coefficients (for all the regressions we used the Ordinary Least Squares standard method). Thus, to estimate the coefficients $\mathrm{a} 1$ and $\mathrm{b} 1$ we selected as initial regression the equation:

$\mathrm{v}=(\mathrm{b} 1 \cdot \mathrm{x} / \mathrm{a} 1)+\left(\mathrm{b} 1^{2} / \mathrm{a} 1\right)+\mathrm{u} 1$

but to estimate a2 and b2 coefficients we used

$\mathrm{zD} \%=\mathrm{a} 2 /(\mathrm{v}+\mathrm{b} 2)+(1-\mathrm{a} 2 / \mathrm{b} 2)+\mathrm{u} 2$

where $\mathrm{u} 1, \mathrm{u} 2$ are residual variances. 
The samples in the 1996 and 2003 surveys on which we applied the first regression procedure (estimating $\mathrm{a} 1$ and $\mathrm{b} 1$ in the relation (10') to introduce them in the relations (6) and (8)) included all the households in the surveys reporting secondary income $(Y>0)$ : S931-96 for September 1996 (there were 931 households in this sample: 775 in the sub-group of households reporting $\mathrm{VD}>\mathrm{V} ; 88$ in the sub-group reporting $\mathrm{VD}=\mathrm{V}$ in the 1996 survey; and 68 in that reporting VD<V) and S88-03 for July 2003 (there were 88 households in this sample: 85 in the sub-group of households reporting VD $>V$ and only 3 households in the sub-group reporting secondary income in July 2003). In Table 3 are synthetically presented the basic data characterising the households' behaviour related to their implication in secondary activities.

The second regression procedure (estimation of a2 and b2 in the relation (7') to introduce them in the relations (9) and (11)) included all households reporting a level of desired income higher than their actual income (or, equivalently, ZD>0): S2181-96 for September 1996 (there were 2181 households in this sample) and S294-03 for July 2203 (there were 294 households in this sample). In Table 4 are synthetically presented the basic data characterising the households' behaviour related to their potential (expected) implication in informal activities.

Table 3. Summary of regression equation output in the case of secondary income

\begin{tabular}{|c|c|c|}
\hline \multirow[b]{2}{*}{$\begin{array}{l}\text { Regression equation and } \\
\text { estimated coefficients }\end{array}$} & \multicolumn{2}{|c|}{ Households reporting $\mathrm{Y}>0$} \\
\hline & $\begin{array}{l}\text { Sep. } 1996 \\
\text { (S931-96) }\end{array}$ & $\begin{array}{c}\text { July } 2003 \\
\text { (S88-03) }\end{array}$ \\
\hline \multicolumn{3}{|l|}{$\mathrm{v}=(\mathrm{b} 1 / \mathrm{a} 1) \mathrm{x}+\left(\mathrm{b} 1^{2} / \mathrm{a} 1\right)+\mathrm{u} 1$} \\
\hline $\begin{array}{l}\text { a1 } \\
(\mathrm{t}-\text { ratio }) \\
(\operatorname{Prob}(\mathrm{t}))\end{array}$ & $\begin{array}{c}11.51066025 \\
(4.870047095) \\
(0.0)\end{array}$ & $\begin{array}{c}2.798577816 \\
(1.107868752) \\
(0.27101)\end{array}$ \\
\hline $\begin{array}{l}\text { b1 } \\
(\text { t-ratio }) \\
(\operatorname{Prob}(t))\end{array}$ & $\begin{array}{c}14.73138239 \\
(5.232932182) \\
(0.0)\end{array}$ & $\begin{array}{c}3.519355431 \\
(1.130105429) \\
(0.26157)\end{array}$ \\
\hline $\mathrm{c} 1=(1-\mathrm{a} 1 / \mathrm{b} 1)$ & 0.21863000 & 0.20480387 \\
\hline $\mathrm{ye}(0)=\mathrm{ve}(0)=\mathrm{b} 1^{2} / \mathrm{a} 1$ & 18.85327361 & 4.42577032 \\
\hline Slope of ye $(\mathrm{x})=(\mathrm{b} 1 / \mathrm{a} 1)-1$ & 0.27980342 & 0.25755139 \\
\hline Slope of $v e(x)=b 1 / a 1$ & 1.27980342 & 1.25755139 \\
\hline $\mathrm{R}^{\wedge} 2$ (Coefficient of Det.) & 0.7575092047 & 0.9642662622 \\
\hline Durbin-Watson Ratio & 1.91203038621 & 2.29281329546 \\
\hline
\end{tabular}

As one may see from the data reported in Tables 3 and 4 there are certain theoretical limits in extending both secondary income and even the desired informal income. Thus, according to the data supplied by the two surveys the minimum share of secondary income in the total actual income (noted as $\mathrm{c} 1$ in Table 3, to which $\mathrm{y} \%$ would asymptotically tend when the main formal income per person, $\mathrm{x}$, would continue to grow very much, $\mathrm{x} \rightarrow+\infty)$ was around $21.9 \%$ of the total formal income $(\mathrm{v}=\mathrm{x}+\mathrm{y}$ or $\mathrm{V}=\mathrm{X}+\mathrm{Y})$ in September 1996 (in the S931-96 case) and 20.5\% in July 2003 (the case of S88-03). Also, even in the case of the desired or expected income there is a minimum share of the informal income in the total expected income (noted as c2 in Table 4, to which $\mathrm{zD} \%$ would asymptotically tend when the formal registered income per person, $v$, would 
continue to increase very much, $\mathrm{x} \rightarrow+\infty$ ), namely around $16.4 \%$ in September 1996 and $24.7 \%$ in July 2003.

Table 4. Summary of regression equation output in the case of desired informal income

\begin{tabular}{|c|c|c|}
\hline \multirow[b]{2}{*}{$\begin{array}{l}\text { Regression equation and estimated } \\
\text { coefficients }\end{array}$} & \multicolumn{2}{|c|}{ Households reporting $\mathrm{V}<\mathrm{VD}$} \\
\hline & $\begin{array}{l}\text { Sep. 1996 } \\
(\mathrm{S} 2181-96)\end{array}$ & $\begin{array}{l}\text { July } 2003 \\
\text { (S294-03) }\end{array}$ \\
\hline \multicolumn{3}{|l|}{$\mathrm{zD} \%=\mathrm{a} 2 /(\mathrm{v}+\mathrm{b} 2)+(1-\mathrm{a} 2 / \mathrm{b} 2)+\mathrm{u} 2$} \\
\hline $\begin{array}{l}\text { a2 } \\
(\mathrm{t}-\mathrm{ratio}) \\
(\operatorname{Prob}(\mathrm{t}))\end{array}$ & $\begin{array}{c}96.32183317 \\
(11.32606896) \\
(0.0)\end{array}$ & $\begin{array}{c}73.6960427 \\
(5.200303398) \\
(0.0)\end{array}$ \\
\hline $\begin{array}{l}\text { b2 } \\
(\mathrm{t}-\text { ratio }) \\
(\operatorname{Prob}(\mathrm{t})) \\
\end{array}$ & $\begin{array}{c}115.2542196 \\
(16.01823627) \\
(0.0) \\
\end{array}$ & $\begin{array}{c}97.88875792 \\
(7.119246168) \\
(0.0) \\
\end{array}$ \\
\hline $\mathrm{c} 2=(1-\mathrm{a} 2 / \mathrm{b} 2)$ & 0.16426632 & 0.24714498 \\
\hline $\mathrm{zDe}(0)=\mathrm{vDe}(0)=\mathrm{b} 2^{2} / \mathrm{a} 2$ & 137.90783147 & 130.02338492 \\
\hline Slope of $\mathrm{zDe}(\mathrm{v})=(\mathrm{b} 2 / \mathrm{a} 2)-1$ & 0.19655343 & 0.32827699 \\
\hline Slope of $\mathrm{vDe}(\mathrm{v})=\mathrm{b} 2 / \mathrm{a} 2$ & 1.19655343 & 1.32827699 \\
\hline $\mathrm{R}^{\wedge} 2$ (Coefficient of Det.) & 0.3994546661 & 0.4289735371 \\
\hline Durbin-Watson Ratio & 2.0277951897 & 1.97130767761 \\
\hline
\end{tabular}

The estimation procedure permits (by replacing the argument $\mathrm{v}$ in $\mathrm{zDe}(\mathrm{v})$ function with the sum $\mathrm{x}+\mathrm{ye}(\mathrm{x}))$ to outline structural prototypes in the case of the two surveys. A general representation is shown in Figure 2 (where the estimated lines for the July 2003 survey are thicker than those for the September 1996 survey). The secondary income share in the total desired income of household is different from its share in the formal actual income. Thus, it is asymptotically increasing as the income provided by the work in the main activity of household increases, tending at limit to constant values: $18.3 \%$ in September 1996 and 15.4\% in July 2003, respectively. Certain behavioural regimes can be outlined: in the case of households having low incomes from their main activity there is a huge availability of the people to work in the informal sector; for the rich people, having considerable incomes from their work in the formal sector, their availability for informal jobs becomes smaller; however still remain certain temptations for the richest people to accept informal jobs in order to supplement their incomes and, perhaps, to avoid taxation. Despite a general decreasing trend of the desired informal income share along with the growth of the basic formal income of household, in absolute terms the desired informal income has an ascending trend, as shown in Figure 3. 


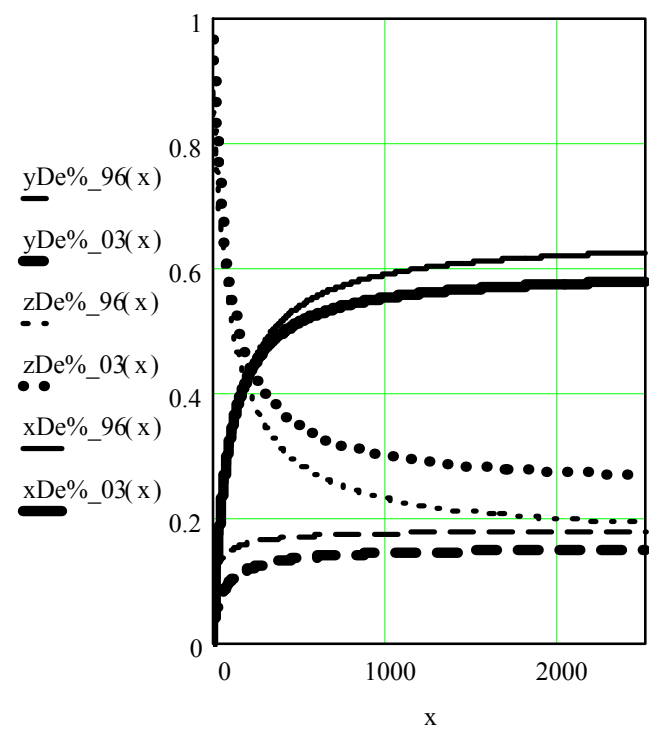

Figure 2.

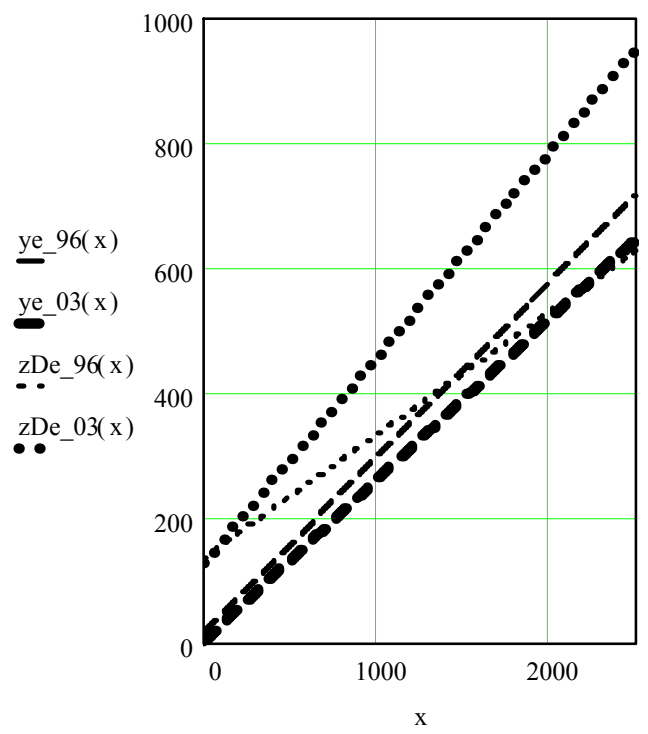

Figure 3.

\section{Regimes related to the households' effective informal income}

As it was already mentioned, we issued to compute indirectly the true level of effective informal income only in the case of the September 1996 survey for the sample S380 (comprising 288 households reporting V=VD, and 92 households reporting $\mathrm{V}>\mathrm{VD}$, respectively). Remember that on the basis of a deeper analysis of the data in surveys we identified three categories of total income to which the answers in households were referring: 1) total official reported income of a household, noted as $\mathrm{V}$, as it appeared in IHS, in September 1996, and in the survey of July 2003, respectively, as an aggregate estimate noted by the data collectors on the household's survey document (in fact this category of total income comprised income obtained in the formal sector only, as main or basic registered income, $\mathrm{X}$, and as income from secondary but formally registered activities, Y); 2) total desired income, noted VD, as it was reported (declared) in SSHIE of September 1996 and in the survey of July 2003, respectively; and 3) total effective income, noted as VR, which we computed indirectly in the case of households reporting $\mathrm{V} \geq \mathrm{VD}$ (380 households in the survey of September 1996 and only 6 cases in the survey of July 2003).

In fact, in the case of the 1996 survey, within the group of 288 households claiming that their actual income equals their desired income, the assertion is true only for 60 cases (thus, only in the case of 60 households $\mathrm{V}=\mathrm{VD}=\mathrm{VR}$ and, consequently, they do not effectively obtain informal income, $Z=0$ ). For the remaining 228 households within the group S288, the assertion is a false one, when the formal reported income, V, is compared with the level claimed as desired income, VD, but it becomes true in the case of considering the effective (but not reported) income, VR (thus, in this case the total effective income of household is higher than its total formal reported income, $\mathrm{V}<\mathrm{VR}=\mathrm{VD}$ and, consequently, the household effectively obtains informal income, $\mathrm{Z}>0$ ).

Thus, grouping now the households in the sample S380 by the criterion of effective participation in informal sector, we obtained a new structure: a number of 228 households effectively obtaining informal income $(Z>0)$ and 152 households not effectively obtaining informal income $(Z=0)$, respectively. The latter was formed by 
adding to the group of 92 households reporting $\mathrm{V}>\mathrm{VD}$ (consequently, they had no effective informal income, $Z=0$ ) the group of 60 households coming from the former group of 288 households initially claiming $\mathrm{V}=\mathrm{VD}$ and in fact having $\mathrm{V}=\mathrm{VD}=\mathrm{VR}$.

Table 5 presents the structure by sources of the total income within the sample S380, this time divided in two groups according to the criterion of effective participation of household in the informal sector. Also, based on the S380 data we computed the regression equations related to the household's effective participation in the informal sector. Then, in last part of the paper, the regression output will be used to obtain an estimate for the size of informal economy in Romania, taking into account the entire population of households and its structure by deciles according to the NIS published data for the 1995-2002 period.

Table 5. Structure of total income in the case of the 380-sample (V $\geq V D)$

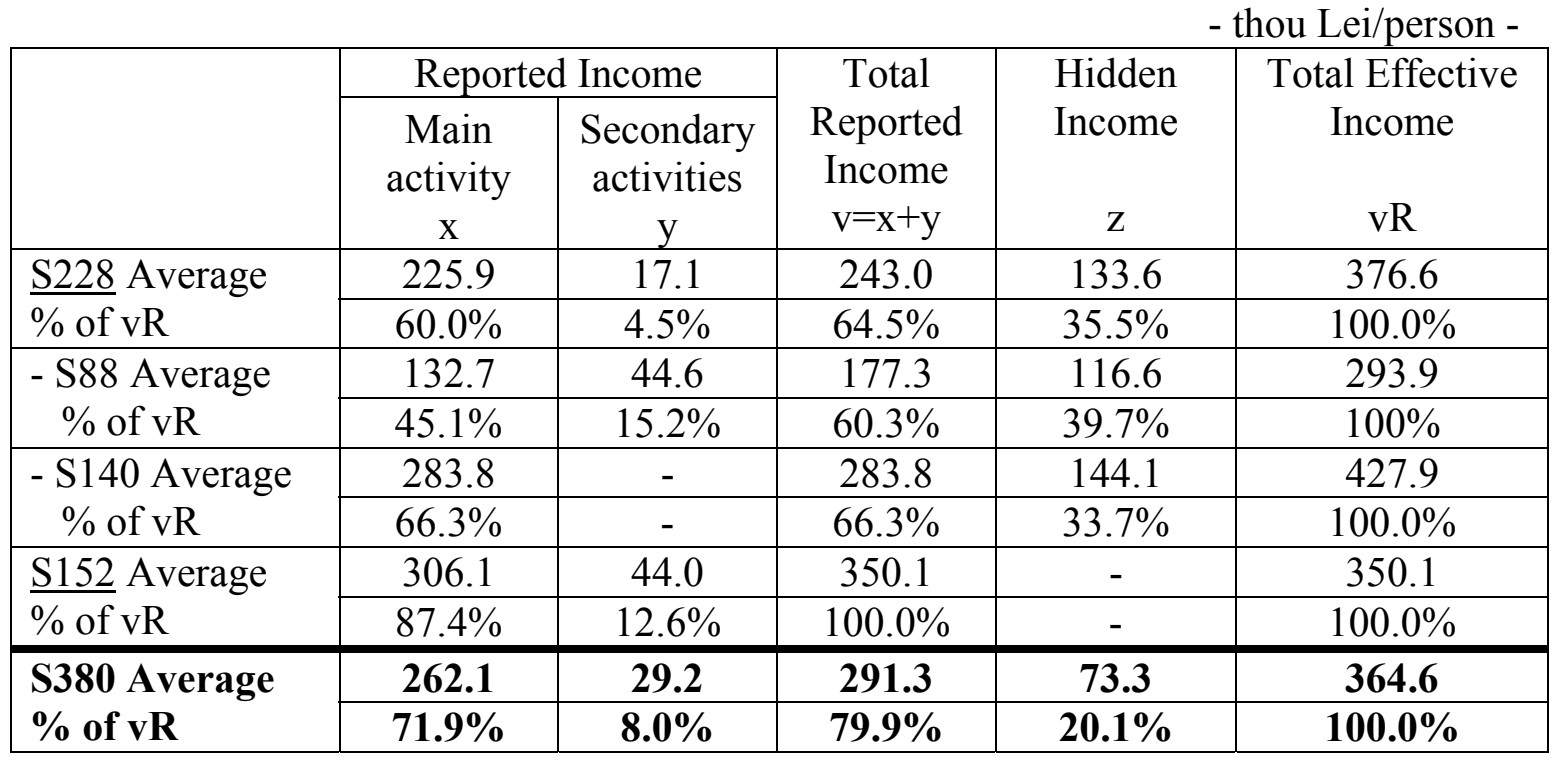

Corresponding to the data in Table 5, for the entire 380-sample the share of the informal (hidden) income, z/vT, was around $20.1 \%$ on average and around $35.5 \%$ in the case of the households being involved in informal activities, respectively. In other words, the composition of a household total income in the sample S380, VT, was provided in September 1996 by the following sources: $71.9 \%$ main activity, $8.0 \%$ secondary activity, and $20.1 \%$ informal activity.

Thus, the last estimated share of informal income, $20.1 \%$ of total income, may be used as a first estimation in order to obtain parameters in a general regression equation and to characterise, for the entire population of households, the behaviour of households related to their effective participation in the informal area. The other alternative is to estimate the regression equation only in the case of households implied in informal activities. Then, in order to obtain an estimate of the share of informal income at the national level we must penalise the regression equation by the proportion of households operating in informal sector in the total population. Thus, we must make hypothesis on the probability that a household finds within the set of the households operating in the informal sector. The simplest solution is to consider as a first raw estimator of this probability the same proportion of people operating in informal sector as it is computed in the case of the sample S380. Indeed, introducing this hypothesis will additionally 
imply to consider a similar distribution of the whole population as in the case of the sample S380. However, taking into account that other accurate sources of more analytical information related to the proportion of households involved in informal activities are not available at this moment, it remains to expand the regression output from the sample S380 to the national level by using only the available distribution of households' population by deciles as it is yearly published by NIS. As the empirical available data in the case of the two surveys suggest, the best general fitting function to estimate the household's behaviour seems to be one expressing a complex inverse relation between the average level of income provided by the work in the formal sector (main activity and secondary activities) and the participation rate in the informal sector (computed as the share of informal income in the total effective income in the case of the sample S380).

Also, in the case of samples S380, as in that of S2181 already analysed in the last section, we can affirm that households tend to involve more and more (as proportion) in informal sector as their formal income is lower. The difference is that now, in the case of S380, the informal income is effectively obtained as against the potential informal income reported in the case of the 2181 sample. As one may see, the mentioned tendency is only in relative terms, because in absolute terms the level of informal income generally is also increasingly higher when the level of income from the formal sector grows.

Indeed, together with the level per person of formal income in absolute terms we should consider many other factors as stimulating households to involve in the informal sector, such as occupation, region, age, education, etc., as we proceeded in a former special study. However, in the context of this paper certain useful conclusions could be outlined:

- People in households perceive the high rate of taxation as the main cause of the underground activity (more than $80 \%$ of the answers in surveys demonstrate this idea).

- Separating the main motivations of operating in informal sector in two groups "subsistence" and "enterprise", respectively, the data in surveys suggest that the subsistence represented a relevant reason for the households' decision to operate in the informal sector.

- Informal activities supply a "safety valve" within the surviving strategies adopted by the poorest households.

- Participation in the informal sector seems to be not simply correlated with poverty: in the informal activities are involved poor people (having probably a low educational level), as well as relatively rich persons. However, their motivations are quite different. The former are practically "forced" to operate in the informal sector (the "subsistence" criterion), but the latter are "invited" to participate in it (the "enterprise" criterion). In both cases, at least during the last stages of transition to a free market system in Romania, the environment was propitious due to legislative incoherence, feeble penalty system in the cases of fraudulent activities, and existence of some accompanying elements of proper informal activity, such as corruption, bureaucracy, etc. However, the behaviour related to the informal economy is sometimes fundamentally different between the two groups of population. The most synthetic expression of this idea could be as follows: along with the growth of their formal income households tend to desire to obtain more and more informal income in absolute terms, but at the same time its share in the total income tends to decrease (sharply down until a reasonable average level of formal income is obtained and slowly down in the case of the richest households). Probably, the main reason for which the rich people could be involved in the informal sector is provided by the attempt to avoid taxes and to follow an optimising strategy in this matter. 
Regarding the regimes in the case of households' effective informal income, as a general overview they are similar to those in the case of desired informal income, but they are very different as regards the concrete values of the parameters and levels.

Relatively similar to the case of desired informal income in the previous section of this paper, we used again the hypothesis of a hyperbolic-type function for $z \%(v)$. This time $\mathrm{z}$ means the effective informal income, in order to make difference from the desired informal income, zD. Also, in order to estimate the coefficients we selected as basic regression equation that expressing the share of informal income in the total household's income, $\mathrm{z} \%$, as being correlated with the level of the formal income in household, as follows:

$\mathrm{z} \%=\mathrm{a} /(\mathrm{v}+\mathrm{b})+(1-\mathrm{a} / \mathrm{b})+\mathrm{u}$

where $a, b$ are coefficients to be estimated and $u$ is residual variance.

Now, using the estimated values of coefficients we can write, along with changes in the level of formal income, the expected trajectories, as follows:

$\mathrm{ze} \%=\mathrm{a} /(\mathrm{v}+\mathrm{b})+(1-\mathrm{a} / \mathrm{b})$

$\mathrm{ze}(\mathrm{v})=[(\mathrm{b}-\mathrm{a}) / \mathrm{a}] \cdot \mathrm{v}+\left(\mathrm{b}^{2} / \mathrm{a}\right)$, with $\mathrm{ze}(0)=\left(\mathrm{b}^{2} / \mathrm{a}\right)$

and, respectively

$\operatorname{vRe}(v)=(b / a) \cdot v+\left(b^{2} / a\right)$, with $v \operatorname{Re}(0)=z e(0)=\left(b^{2} / a\right)$

The samples of the September 1996 survey on which we applied the regression procedure were S380 and the sub-sample S228, respectively (in the case of the 2003 survey there is no possibility to evaluate the effective informal income). Table 6 synthetically presents the basic data characterising the households' behaviour related to their effective informal income. From the data in this table resulted a limit-value for the share $\mathrm{z} \%(+\infty)$ of around $2.1 \%$ in the case of the 380 -sample (representing an estimator of the average value in the case of the entire population of households) and $9.4 \%$ in the case of considering only the households involved in the informal sector.

Table 6. Summary of regression equation output in the case of real informal income

\begin{tabular}{|l|c|c|}
\hline Regression equation and estimated & \multicolumn{2}{|c|}{ Households reporting V $\geq \mathrm{VD}$} \\
\cline { 2 - 3 } coefficients & $\mathrm{S} 380-96$ & $\mathrm{~S} 228-96$ \\
\hline $\mathbf{z} \%=\mathbf{a} /(\mathbf{v}+\mathbf{b})+(\mathbf{1 - a} / \mathbf{b})+\mathbf{u}$ & & \\
\hline $\mathrm{a}$ & 40.20288127 & 52.28482256 \\
$(\mathrm{t}-\mathrm{ratio})$ & $(5.78891877)$ & $(4.515511099)$ \\
$($ Prob$(\mathrm{t}))$ & $(0.0)$ & $(0.00001)$ \\
\hline $\mathrm{b}$ & 41.08227834 & 57.730209 \\
$(\mathrm{t}-\mathrm{ratio})$ & $(6.649225468)$ & $(5.463029131)$ \\
$($ Prob $(\mathrm{t}))$ & $(0.0)$ & $(0.0)$ \\
\hline $\mathrm{c}=(1-\mathrm{a} / \mathrm{b})$ & 0.02140575 & 0.0943247311 \\
\hline $\mathrm{vCr}=\mathrm{b}^{2} /(2 \mathrm{a}-\mathrm{b})$ & 42.91973684 & 71.15322701 \\
\hline $\mathrm{ze}(0)=\mathrm{ve}(0)=\mathrm{b}^{2} / \mathrm{a}$ & 41.98091132 & 63.74272433 \\
\hline $\mathrm{Slope} \mathrm{of} \mathrm{ze}(\mathrm{v})=(\mathrm{b} / \mathrm{a})-1$ & 0.02187398 & 0.10414851 \\
\hline Slope of $\mathrm{vRe}(\mathrm{v})=\mathrm{b} / \mathrm{a}$ & 1.021873981 & 1.1041485114 \\
\hline $\mathrm{R}^{\wedge} 2(\mathrm{Coefficient}$ of Det.) & 0.256104055 & 0.3420802227 \\
\hline
\end{tabular}


A general representation of the estimation function for S380 and S228 is shown in Figure 4 (where the estimated lines for the sub-sample S228, solid line and dashed line, are thicker than those for the sample S380). Also, on graphs are marked the critical values of $\mathrm{v}, \mathrm{vCr} 380$ and $\mathrm{vCr} 228$, respectively, for which the informal income share equals the share of formal income in the total real income of household. One may see an important positive shift of the function $\mathrm{z} \%(\mathrm{v})$ to the upper side of graph in the case of translation from S380 to S228.

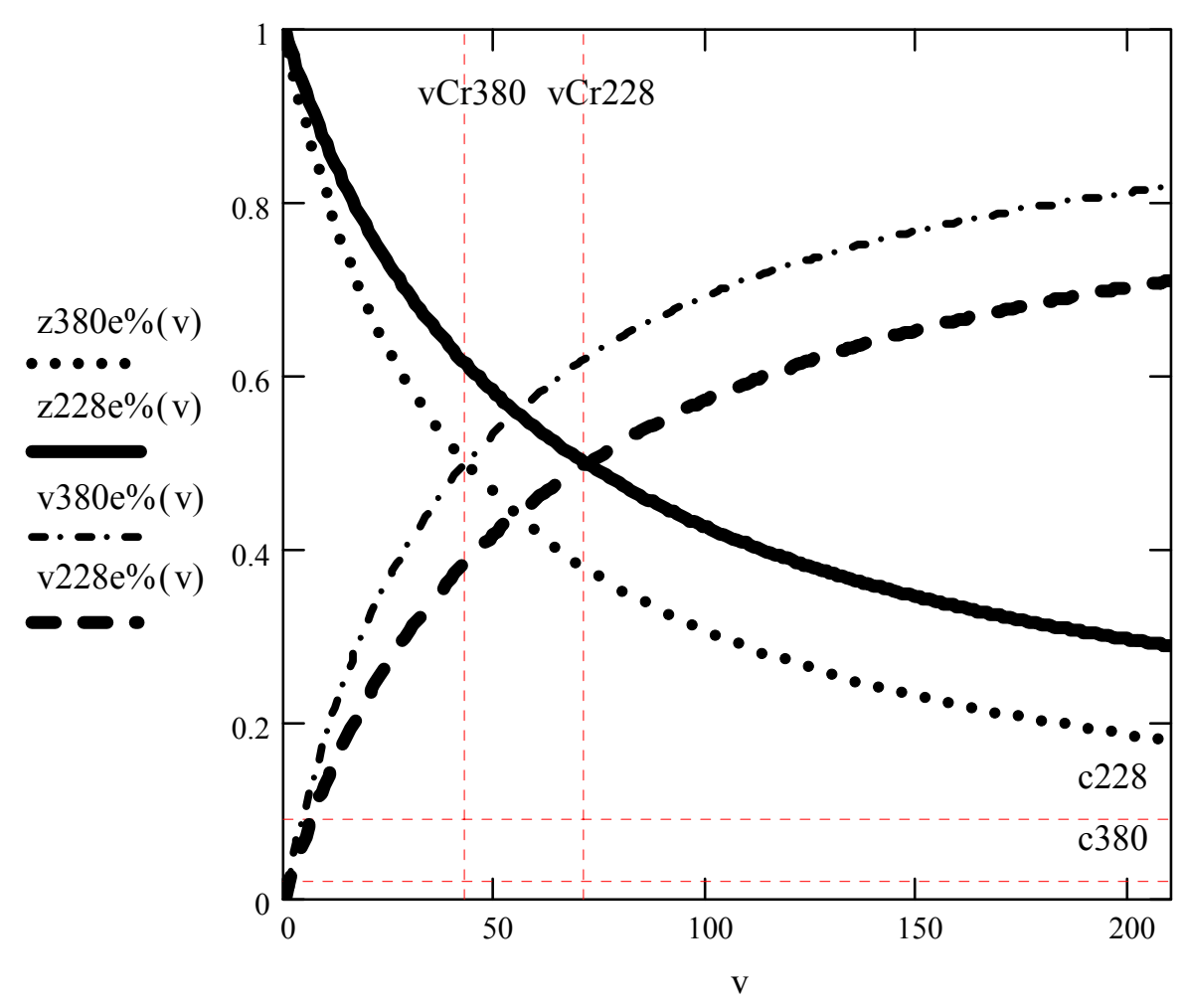

Figure 4.

Remember that in the case of the sample S380 the function of informal income share reflects indirectly also the impact of changing the proportion of households operating in the informal sector (or, equivalently: the impact of changing the probability that a household is involved in the informal sector) along with the growth of the formal income per person in household. Consequently, it could be used directly to expand the estimation procedure to the national level. An impediment remains: it is implicitly supposed the same distribution of the entire population by formal income as in the case of the S380 sample. On the other hand, the sample S228 comprises only the households that obtain informal income. In this case, to simply extrapolate the $\mathrm{z} \%(\mathrm{v})$ function to the entire set of households' population is not a good solution. Thus, firstly we have to amend the $z \%(v)$ function by multiplying it with the probability function computed, for instance, by deciles, as we shall proceed in the next section of the paper.

It is also interesting to compare the estimated function for informal income in the case of the sample S2181, comprising only "pure" potential (desired) informal income reported by households, and that in the case of the S228 sample, including only "pure" 
effective informal income reported by households (all households in S228 obtained effective informal income). For the sample S2181 it is completely unknown how high the real informal income is, but surely all households in the sample wish to work even in the informal sector in order to obtain income to be added to their actual income in the formal sector, considered as insufficient. The behaviour of the two functions of the informal income is visualised in Figure 5. Also, on the graph in this figure, according to the available data in the September 1996 survey, it is accentuated the area between the estimated function of the potential informal income $(\mathrm{zD} 2181 \mathrm{e} \%)$ and the estimated function of the real informal income (z228e\%), which can be interpreted as uncovered demand of households for informal income. The real supply of informal jobs and opportunities to work in informal activities is probably smaller than it is represented by the inferior frontier of that designed area.

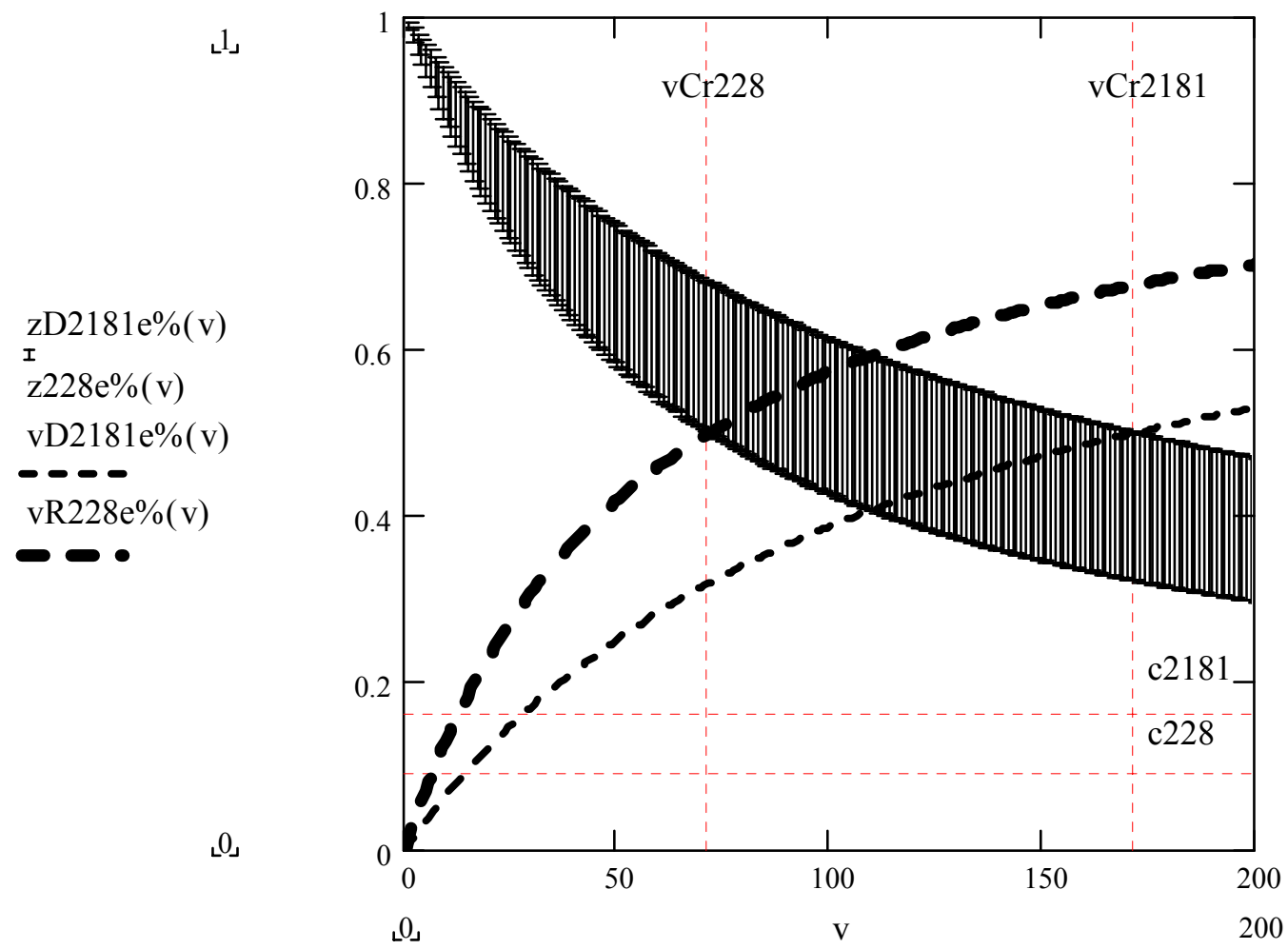

Figure 5.

\section{Expanding the estimation of informal income to the national level}

In order to obtain an estimation of the size of informal income at national level several steps were followed:

1) Computing the level of the formal income for the entire year 1996 in constant September 1996 prices (thus, based on the monthly reported CPI, we computed a value of 1.09081185 for the correction coefficient).

2) Using the yearly reported index of consumer prices and the data published by NIS regarding the households' distribution by deciles of income and by average number of persons, we prepared the complete and compatible data base necessary in the estimation process for each year of the period 1995-2002. 
3) Extrapolating the output of the regression equation selected in the case of the sample S380 (supposed to reflect correctly the entire population of households regarding their behaviour related to the participation in the informal sector) to estimate the level of real income and, consequently, that of the real informal income at the level of the entire population of households structured by deciles of formal income per person in Romania for each year of the analysed period.

4) Extrapolating the output of the regression equation used already in the case of the sample S228 to the entire population in the analysed period in order to obtain an estimate for the superior value of informal income share (it is plausible only in the case when all households are involved in informal activities, as it is the case of the sample S228).

5) Amending the last estimating equation by adding a supplementary equation concerning the probability that a person in a household is involved in the informal economy. This was estimated by regressing within the sample S380 the proportion of persons in households obtaining effectively informal income in the total number of the deciles in which they are located (the total number of this special category of household is just the sample S228):

$\mathrm{p}=\mathrm{a} \cdot \mathrm{d}+\mathrm{b}+\mathrm{u}$

and from which the equation (13) is rewritten as

$\mathrm{zpe}(\mathrm{v})=\mathrm{ze}(\mathrm{v}) \cdot \operatorname{pe}(\mathrm{d})$

where $d$ are deciles $(d=1 \ldots 10)$; pe $(d)=a d+b$ is the estimation equation of the probability that a person in a household is involved in the informal economy, $\mathrm{p}$; $\mathrm{a}$ and $\mathrm{b}$ are the estimated coefficients, and $\mathrm{u}$ is residual variance in the equation (15). Table 7 synthetically presents the basic data characterising the regression equation (15).

6) Comparing the three estimating procedures and their outputs.

Table 7. Summary of the regression equation (15)

\begin{tabular}{|l|c|}
\hline $\begin{array}{l}\text { Regression equation and estimated } \\
\text { coefficients }\end{array}$ & $\begin{array}{c}\text { Households with Z }>0 \text { (S228-96) } \\
\text { within sample S380-96 }\end{array}$ \\
\hline $\mathbf{p}=\mathbf{a} \cdot \mathbf{d}+\mathbf{b}+\mathbf{u}$ & -0.02987557576 \\
$\mathrm{a}$ & $(-2.037636312)$ \\
$(\mathrm{t}-\mathrm{ratio})$ & $(0.07595)$ \\
$($ Prob(t)) & 0.7067002667 \\
$\mathrm{~b}$ & $(7.768108416)$ \\
$(\mathrm{t}-$ ratio $)$ & $(0.00005)$ \\
(Prob(t)) & 0.34167008 \\
\hline $\mathrm{R}^{\wedge}$ (Coefficient of Det.) & 1.23928982856 \\
\hline Durbin-Watson Ratio & \\
\hline
\end{tabular}

Very synthetically, the conclusion is that over the period 1995-2002 the informal income increased in Romania from around $18 \%$ in the total real income of households in 1995 to near $21 \%$ in 2002, with a maximum level of around $22 \%$ in 1999 and 2000. Under the very improbable hypothesis of a generalised participation in informal activities, the computed share value grew from $29 \%$ in 1995 to near $32 \%$ in 2002 (with a minimum value of $28 \%$ in 1996 and a maximum value of $33.7 \%$ in 2000 ).

Deeper interesting conclusions could be extracted in the case of analysing by deciles the dynamic process of involvement in the informal sector. Appendix 2 presents the three 
matrices comprising the shares of informal income within the total income in the case of all deciles for each year of the period 1995-2002, corresponding to the three estimating methods. In Appendix 3 is presented the contribution of deciles to the total informal income at national level, also corresponding to the three methods.

Figures 6 and 7 show the estimated dynamics of the informal income share based on the two estimation functions over the period 1995-2002 (the year 1995 is denoted as 1 and 2002 as 8), and their relatively strong direct correlation with the distribution of population number by deciles, respectively. $\mathrm{z} \% \mathrm{M}$, represents the yearly average of the informal income share in the total income at national level, resulted from the regression equation based on the S380 sample and $\mathrm{zp} \% \mathrm{M}$ from that computed on the S228 sample amended by the probability function, respectively. The detailed data for the years of the analysed period are presented in Table 8 .

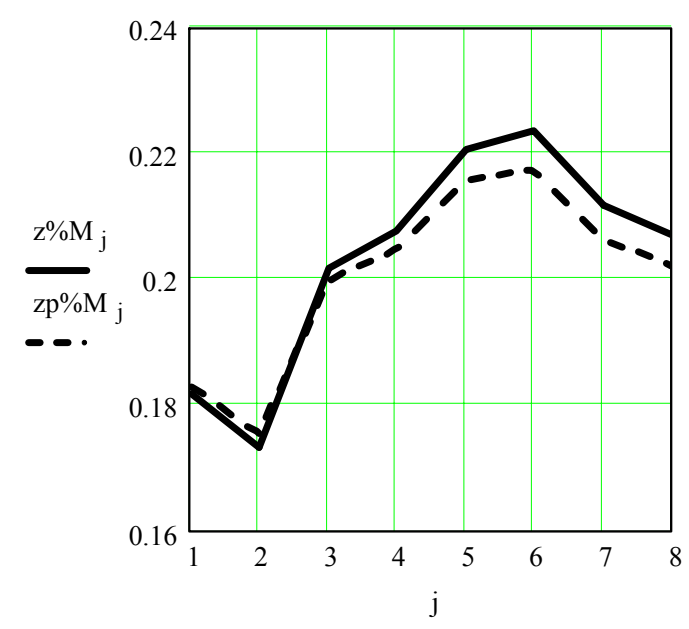

Figure 6.

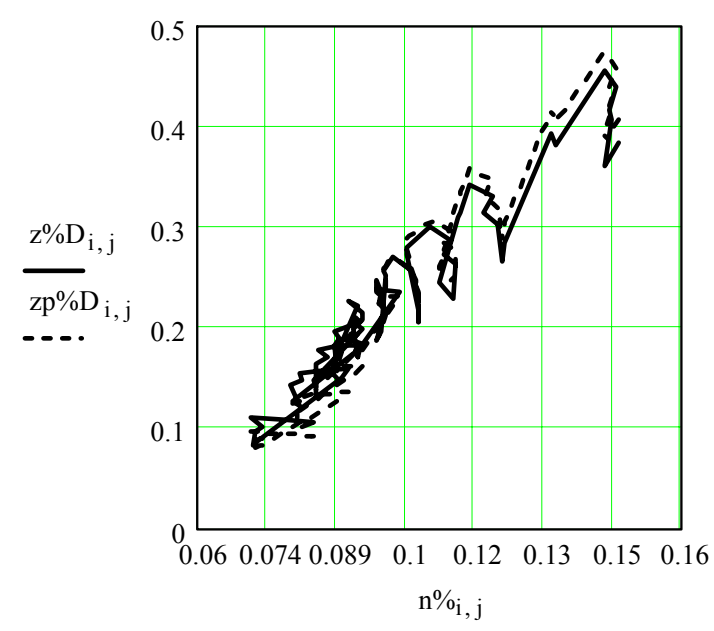

Figure 7.

Table 8 Average shares of informal income in the total income of households over the period 1995-2002

\begin{tabular}{ccc} 
Years & $\mathbf{z \% M}$ & $\mathbf{z p \% M}$ \\
\hline 1995 & 18.2 & 18.3 \\
1996 & 17.3 & 17.5 \\
1997 & 20.2 & 20.0 \\
1998 & 20.8 & 20.5 \\
1999 & 22.1 & 21.6 \\
2000 & 22.3 & 21.7 \\
2001 & 21.2 & 20.6 \\
2002 & 20.7 & 20.2
\end{tabular}

Finally, Figures 8 and 9 show as graphical representations the strong inverse correlations emerging in the case of grouping the households' population by deciles, 
which are fundamentally determined by the average level per person in household: $\mathrm{v}-\mathrm{z} \%$ and $\mathrm{v}-\mathrm{n}$, respectively (as average number in household, $\mathrm{n}$, or as share of deciles in total number of persons, $\mathrm{n} \%$ ). As we tried to demonstrate in this study, despite the inverse correlation between $\mathrm{v}$ and $\mathrm{z} \%$, the formal income and the absolute level of informal income are strongly directly correlated (it worth noticing that in the case of considering $\mathrm{zp} \%$ the correlation is more complicated, seeming to demonstrate a minimum local placed around of an average formal income of $300000 \mathrm{Lei} /$ person/month in September 1996 prices).

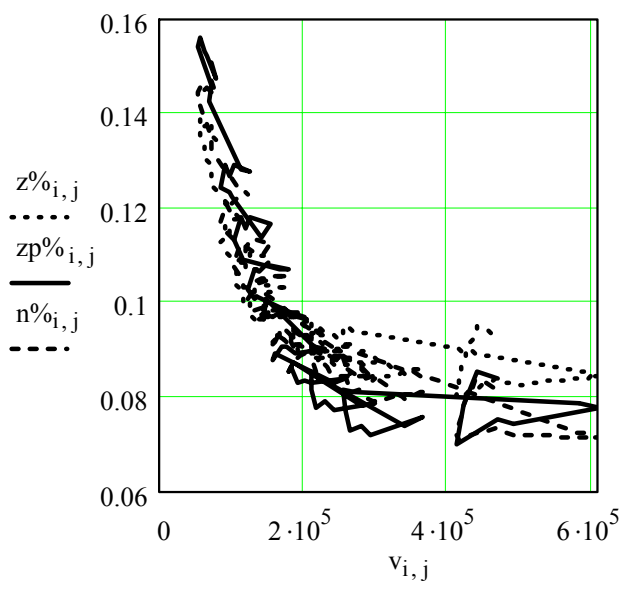

Figure 8

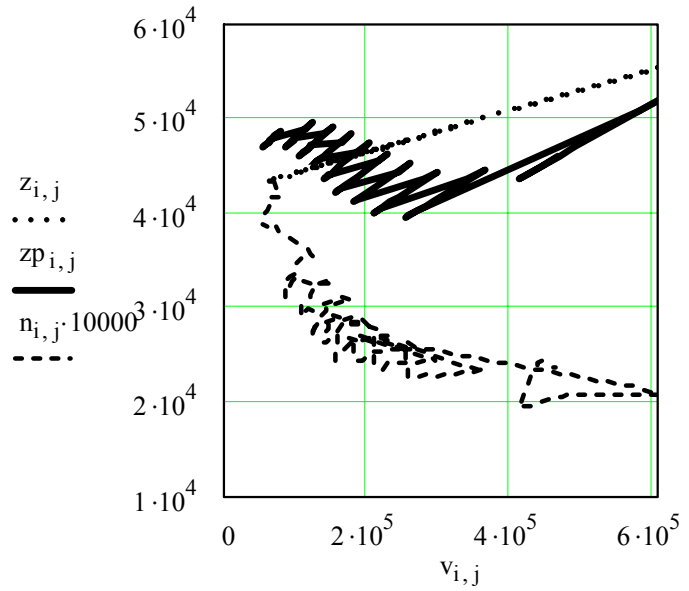

Figure 9.

\section{Selected bibliography}

Adair, P. (1985): L'économie informelle - Figures et discours, Anthropos.

Albu, L.-L. (1995): Underground Economy and Fiscal Policies Modelling, ACEPhare Project, Université de Paris I, Centre d'Etudes Prospectives d'Economie Mathematique Appliquées à la Planification, August.

Albu, L.-L. (2001):"'Estimating the size of underground economy", in: Proceedings of the Romanian Academy, Series C: Humanities and Social Sciences, Vol. 1, No. 2-3, Bucharest.

Albu, L.-L. (2001): "Tax Evasion and the Size of Underground Economy: a Theoretical and Empirical Investigation", in: Romanian Journal of Economic Forecasting, Vol. 1-2 (5-6), Bucharest.

Albu, L.-L., Daianu, D., Pauna, B., and Pavelescu, F. (1998): "Endogenous Cycles and Underground Economy in Europe", MEET-IV conference on the East European Economies in Transition, University of Leicester - CEES, 20-21 June.

Albu, L.-L., Kim, B.-Y., and Duchene, G. (2002): "An Attempt to Estimate the Size of Informal Economy Based on Household Behaviour Modelling", in: Romanian Journal of Economic Forecasting, Vol. 1 (9), Bucharest. 
Albu, L.-L., Kim, B.-Y., and Duchene, G. (2002):'Households' Activities in Informal Economy: Size and Behavioural Aspects", in: Romanian Journal of Economic Forecasting, Vol. 3-4 (11-12), Bucharest.

Albu, L.-L. and Nicolae, M. (2002): "Use of Households Survey Data to Estimate the Size of the Informal Economy in Romania", in: The Informal Economy in the EU Accession Countries: Size, Scope, Trends and Challenges to the Process of EU Enlargement, Network for Integration of Central and Eastern-European Countries into the European Union, March, Sofia.

Albu, L.-L., Tarhoaca, C., and Ivan-Ungureanu, C. (2001): Study of informal economy in Romania, CRPE, IRIS, Bucharest.

Allingham, M.G. and Sandmo, A. (1972): "Income Tax Evasion: A Theoretical Analysis", Journal of Public Economics, November, 1(3-4).

Archambault, E. and Greffe, X. (1984): Les économies non officielles, La Decouverte.

Bhattacharyya, D.K. (1999): On the Economic Rationale of Estimating the Hidden Economy, The Economic Journal 109/456, pp. 348-359.

Blades, Derek (1982): "The Hidden Economy and the National Accounts", OECD (Occasional Studies), Paris, pp. 28-44.

Cagan, Phillip (1958): "The Demand for Currency Relative to the Total Money Supply," Journal of Political Economy, 66:3, pp. 302-328.

Clotfelter, C.T. (1983): "Tax Evasion and Tax Rates: An Analysis of Individual Returns", Review of Economics and Statistics, Vol. 65.

Cowell, F. (1985):'Tax Evasion with Labour Income", Journal of Public Economics, February, 26(1).

Cowell, F. (1990): Cheating the government, Cambridge MA: MIT Press.

Daianu, D. and Albu, L.-L. (1997):'Institutions, Strain and the Underground Economy". International Conference on the Importance of the Underground Economy in Economic Transition, University of Zagreb. The Davidson Institute Working Paper Series, 98.

Dobrescu, E. (1996): Macromodels of the Romanian Transition, EXPERT Publishing House, Bucharest.

Duchene, G., (1999): "Les revenues informels en Roumanie. Estimation par enquete", in: Revue d'etudes comparatives Est-Ouest, vol. 30, no. 4, Paris.

Duchene, G. (coordinator), Adair, P., Albu, L.-L., Ivan-Ungureanu, C., Neff, R., and Tanase, F. (1998): Informal economy in Romania, ACE-Phare Project, ROSES, Paris, September.

Feige, Edgar L. (1989) (ed.): The underground economies. Tax evasion and information distortion. Cambridge, New York, Melbourne, Cambridge University Press.

Feldstein, M. (ed.) (1983): Behavioural Simulation Methods in Tax Policy Analysis, The University of Chicago Press.

Fortin, B. and Hung, N.M. (1987): "Poverty trap and the hidden labour market", Economics Letters, No. 25.

Fortin, B. and Lacroix, G. (1994): "Labour supply, tax evasion and the marginal cost of public funds. An empirical investigation", Journal of Public Economics, 55(3), November.

French, R., Balaita, M. and Ticsa M. (1999): "Estimating The Size And Policy Implications Of The Underground Economy In Romania", US Department of the Treasury, Office of Technical Assistance, Bucharest, August.

Frey, Bruno S. and Hannelore Weck-Hannemann (1984): The hidden economy as an "unobserved" variable, European Economic Review, 26/1, pp. 33-53. 
Frey, Bruno S. and Werner Pommerehne (1984): The hidden economy: State and prospect for measurement, Review of Income and Wealth, 30/1, pp. 1-23.

Gibson, B. and Kelley, B. (1994):"A Classical Theory of the Informal Sector", The Manchester School, Vol. LXII, 1.

Gutmann, Pierre M. (1977): “The Subterranean Economy,” Financial Analysts Journal, 34:1, pp. 24-27.

Hénin, P.-Y. (1986): Equilibres avec rationnement d'une économie a planification centralisée et secteur paralléle: une analyse macroéconomique, Revue d'économie politique, No. 3.

Isachsen, A.J., and Strom, S. (1980): The hidden economy: The labour market and tax evasion, Scandinavian Journal of Economics, 82.

Jung, Y.H., Snow, A., and Trandel, G.A. (1994):"The evasion and the size of the underground economy", Journal of Public Economics, Vol. 54.

Kesselman, J.R., (1989): Income tax evasion: An intersectoral analysis, Journal of Public Economics, Vol. 38.

Lackó Mária (1997): Do power consumption data tell the story? (Electricity Intensity and the hidden economy in Post-Socialist countries), Laxenburg: International Institute for Applied Systems Analysis (IIASA), working paper.

Lemieux, T., Fortin, B., and Fréchette, P. (1994):'The Effect of Taxes on Labour Supply in the Underground Economy", The American Economic Review, March, 84(1).

Pencavel, J.H. (1979), A Note on Income Tax Evasion, Labour Supply, and Nonlinear Tax Schedules, Journal of Public Economics, Vol. 12.

Pestieau, P. (1989): L' Economie souterraine, Hachette, Pluriel.

Pestieau, P. and Possen, U. M. (1991): "Tax evasion and occupational choice", Journal of Public Economics, Vol. 45.

Portes, A., Castells, M. and Benton, L.A. (1989): The informal economy: Studies in advanced and less developed countries, Baltimore, MD: John Hopkins University Press.

Sandmo, A. (1981): Income Tax Evasion, Labour Supply, and the Equity-Efficiency Tradeoff, Journal of Public Economics, 16(3), December.

Smith, S. (1986): Britain's Shadow Economy, Clarendon Press, Oxford.

Schneider, Friedrich (1994): Can the shadow economy be reduced through major tax reforms? An empirical investigation for Austria, Supplement to Public Finance/ Finances Publiques, 49, pp. 137-152.

Schneider, Friedrich (2002): "The Size and Development of the Shadow Economies and Shadow Economy Labour Force of 22 Transition and 21 OECD Countries: What Do We Really Know?", in: The Informal Economy in the EU Accession Countries: Size, Scope, Trends and Challenges to the Process of EU Enlargement, Network for Integration of Central and Eastern-European Countries into the European Union, March, Sofia.

Schneider, Friedrich and Dominik Enste (2000): Shadow Economies: Size, Causes, and Consequences, The Journal of Economic Literature, 38/1, pp. 77-114.

Schneider, F. and Neck, R. (1992): "The development of the shadow economy under changing tax systems and structures: some (tentative) empirical results for Austria", International Seminar in Public Economics, Escorial (Madrid), June 11-12.

Smith, S. (1986): Britain's Shadow Economy, Clarendon Press.

Tanzi, Vito (1982) (ed.): The underground economy in the United States and abroad, Lexington (Mass.), Lexington.

Thomas, J., (1992): Informal Economic Activity, Harvester Wheatsheaf, London.

Tobin, J. (1969): Comment on Borch and Feldstein, Review of Economic Studies, Vol. 36. 
Watson, H. (1985): Tax evasion and labour markets, Journal of Public Economics, Vol. 27.

Yaniv, G. (1994): Tax Evasion and the Income Tax Rate: a Theoretical Reexamination, Public Finance, Vol. 49.

Yitzhaki, S. (1974): A Note on Income Tax Evasion: A Theoretical Analysis, Journal of Public Economics, 3(2), May.

*** National Institute of Statistics (1996-2003): Population income, expenditure and consumption, Romanian Statistical Yearbook 1996-2003, Bucharest. 
List of questions regarding income included in the sample questionnaire used in July 2003

1. Value of household incomes obtained in July 2003 (in Romanian ROL*)

- below $\quad 1.500 .000$

- between 1.500.000. - 2.500.000

- between $2.500 .001-4.000 .000$

- between $4.000 .001-6.000 .000$

- between 6.000.001-8.000.000

- between $8.000 .001-10.000 .000$

- between 10.000.001-15.000.000

- over 15.000 .000

(Value estimated by the operator)

* Romanian national currency (leu)
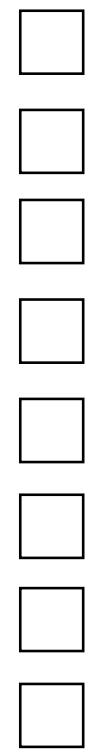

$(\ldots)$

2. In the case there is a secondary activity performed by the persons in the household, can you estimate the ratio of the incomes obtained from the two activities in July 2003?

\begin{tabular}{|c|c|c|c|c|c|c|c|c|c|c|}
\hline & \multicolumn{10}{|c|}{ Code of the person in the household } \\
\hline & 01 & 02 & 03 & 04 & 05 & 06 & 07 & 08 & 09 & 10 \\
\hline & 1 & 2 & 3 & 4 & 5 & 6 & 7 & 8 & 9 & 10 \\
\hline $\begin{array}{l}\text { The ratio of the } \\
\text { incomes from the } \\
\text { two activities }\end{array}$ & & & & & & & & & & \\
\hline
\end{tabular}
activity

*) $1=$ The income from the main activity equals the income from the secondary

$2=$ The income from the main activity is higher than the income from the secondary activity

3 = The income from the main activity is lower than the income from the secondary activity

3. Which monthly income do you consider as being sufficient for your entire household for a "decent living"? 


\section{$1 \quad 1 \quad 1 \quad \mid$}

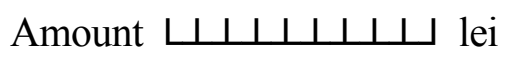

\section{List of questions regarding income included in the sample questionnaire used in September 1996 (SSHIE Survey)}

1. In the case where exists a second activity that is carried out by the persons from the household, could you estimated the ratio of the obtained incomes from these two activities?

\begin{tabular}{|l|c|c|c|c|c|c|c|c|c|c|}
\hline & \multicolumn{8}{|c|}{ Code of person within the household } \\
\cline { 2 - 12 } & 01 & 02 & 03 & 04 & 05 & 06 & 07 & 08 & 09 & 10 \\
\cline { 2 - 11 } & 1 & 2 & 3 & 4 & 5 & 6 & 7 & 8 & 9 & 10 \\
\hline $\begin{array}{l}\text { The ratio of the incomes from } \\
\text { these two activities }\end{array}$ & & & & & & & & & & \\
\hline
\end{tabular}

*) $1=$ the income from the first activity is equal to the income from the second activity

$2=$ the income from the first activity is higher than the income from the second activity

$3=$ the income from the first activity is lower than the income from the second activity

2. Which is the monthly income that will be sufficient to the whole household for a "decent living"?

The amount lei

3. How do you consider that is your existing total income in ratio to the one that would be sufficient for a "decent" living? You should encircle the right answer.

\begin{tabular}{|c|c|c|}
\hline Low & Almost equal & Higher \\
\hline 1 & 2 & 3 \\
\hline
\end{tabular}


Appendix 2

Shares of informal income in total income by deciles

H1 Estimations under the hypothesis of S380 regression equation

\begin{tabular}{llllllllll} 
Years & & $\mathbf{1 9 9 5}$ & $\mathbf{1 9 9 6}$ & $\mathbf{1 9 9 7}$ & $\mathbf{1 9 9 8}$ & $\mathbf{1 9 9 9}$ & $\mathbf{2 0 0 0}$ & $\mathbf{2 0 0 1}$ & $\mathbf{2 0 0 2}$ \\
\hline Deciles & D1 & 0.383 & 0.360 & 0.406 & 0.415 & 0.438 & 0.454 & 0.380 & 0.393 \\
& D2 & 0.283 & 0.266 & 0.303 & 0.313 & 0.330 & 0.342 & 0.314 & 0.310 \\
& D3 & 0.244 & 0.229 & 0.263 & 0.273 & 0.286 & 0.299 & 0.279 & 0.271 \\
& D4 & 0.217 & 0.206 & 0.236 & 0.246 & 0.257 & 0.269 & 0.256 & 0.251 \\
& D5 & 0.196 & 0.186 & 0.216 & 0.224 & 0.234 & 0.246 & 0.238 & 0.234 \\
D6 & 0.179 & 0.171 & 0.198 & 0.206 & 0.214 & 0.225 & 0.222 & 0.217 \\
& D7 & 0.163 & 0.156 & 0.182 & 0.188 & 0.196 & 0.203 & 0.204 & 0.199 \\
D8 & 0.147 & 0.140 & 0.163 & 0.170 & 0.177 & 0.182 & 0.182 & 0.177 \\
& D9 & 0.127 & 0.121 & 0.142 & 0.146 & 0.154 & 0.156 & 0.158 & 0.150 \\
& D10 & 0.086 & 0.083 & 0.097 & 0.100 & 0.110 & 0.109 & 0.105 & 0.100 \\
& Average & $\mathbf{0 . 1 8 2}$ & $\mathbf{0 . 1 7 3}$ & $\mathbf{0 . 2 0 2}$ & $\mathbf{0 . 2 0 8}$ & $\mathbf{0 . 2 2 1}$ & $\mathbf{0 . 2 2 3}$ & $\mathbf{0 . 2 1 2}$ & $\mathbf{0 . 2 0 7}$
\end{tabular}

$\mathrm{H} 2$ Estimations under the hypothesis of S288 regression equation amended by adding the regression equation of probability (S228 in S380)

\begin{tabular}{llllllllll} 
Years & & $\mathbf{1 9 9 5}$ & $\mathbf{1 9 9 6}$ & $\mathbf{1 9 9 7}$ & $\mathbf{1 9 9 8}$ & $\mathbf{1 9 9 9}$ & $\mathbf{2 0 0 0}$ & $\mathbf{2 0 0 1}$ & $\mathbf{2 0 0 2}$ \\
\hline Deciles & D1 & 0.407 & 0.385 & 0.429 & 0.438 & 0.459 & 0.474 & 0.404 & 0.416 \\
& D2 & 0.303 & 0.287 & 0.321 & 0.331 & 0.346 & 0.358 & 0.331 & 0.328 \\
& D3 & 0.257 & 0.244 & 0.274 & 0.283 & 0.295 & 0.308 & 0.289 & 0.282 \\
& D4 & 0.224 & 0.214 & 0.241 & 0.250 & 0.259 & 0.270 & 0.259 & 0.254 \\
& D5 & 0.198 & 0.189 & 0.215 & 0.221 & 0.230 & 0.240 & 0.233 & 0.230 \\
& D6 & 0.175 & 0.168 & 0.190 & 0.197 & 0.204 & 0.213 & 0.210 & 0.206 \\
D7 & 0.154 & 0.149 & 0.169 & 0.174 & 0.180 & 0.186 & 0.186 & 0.182 \\
& D8 & 0.134 & 0.129 & 0.146 & 0.151 & 0.157 & 0.161 & 0.161 & 0.157 \\
& D9 & 0.113 & 0.109 & 0.124 & 0.127 & 0.132 & 0.133 & 0.134 & 0.129 \\
& D10 & 0.080 & 0.078 & 0.087 & 0.089 & 0.095 & 0.095 & 0.092 & 0.089 \\
Average & $\mathbf{0 . 1 8 3}$ & $\mathbf{0 . 1 7 5}$ & $\mathbf{0 . 2 0 0}$ & $\mathbf{0 . 2 0 5}$ & $\mathbf{0 . 2 1 6}$ & $\mathbf{0 . 2 1 7}$ & $\mathbf{0 . 2 0 6}$ & $\mathbf{0 . 2 0 2}$
\end{tabular}

H3 Estimations under the hypothesis of a generalized informal economy (based on the equation of regression used in the case of sample S228)

\begin{tabular}{lccccccccc} 
Years & & $\mathbf{1 9 9 5}$ & $\mathbf{1 9 9 6}$ & $\mathbf{1 9 9 7}$ & $\mathbf{1 9 9 8}$ & $\mathbf{1 9 9 9}$ & $\mathbf{2 0 0 0}$ & $\mathbf{2 0 0 1}$ & $\mathbf{2 0 0 2}$ \\
\hline Deciles & D1 & 0.503 & 0.480 & 0.526 & 0.535 & 0.556 & 0.571 & 0.501 & 0.513 \\
& D2 & 0.401 & 0.383 & 0.422 & 0.433 & 0.450 & 0.463 & 0.434 & 0.430 \\
& D3 & 0.359 & 0.343 & 0.380 & 0.390 & 0.404 & 0.418 & 0.397 & 0.389 \\
& D4 & 0.330 & 0.317 & 0.350 & 0.362 & 0.373 & 0.387 & 0.373 & 0.367 \\
D5 & 0.306 & 0.295 & 0.329 & 0.338 & 0.348 & 0.362 & 0.353 & 0.349 \\
& D6 & 0.286 & 0.277 & 0.308 & 0.317 & 0.327 & 0.339 & 0.335 & 0.330 \\
D7 & 0.268 & 0.260 & 0.290 & 0.297 & 0.306 & 0.314 & 0.315 & 0.309 \\
& D8 & 0.249 & 0.241 & 0.268 & 0.276 & 0.284 & 0.290 & 0.290 & 0.285 \\
& D9 & 0.226 & 0.218 & 0.244 & 0.249 & 0.258 & 0.260 & 0.262 & 0.254 \\
& D10 & 0.176 & 0.173 & 0.190 & 0.193 & 0.205 & 0.204 & 0.199 & 0.194 \\
Average & $\mathbf{0 . 2 9 0}$ & $\mathbf{0 . 2 8 0}$ & $\mathbf{0 . 3 1 2}$ & $\mathbf{0 . 3 1 9}$ & $\mathbf{0 . 3 3 4}$ & $\mathbf{0 . 3 3 7}$ & $\mathbf{0 . 3 2 4}$ & $\mathbf{0 . 3 1 8}$
\end{tabular}


Appendix 3

Shares of informal income in total income by years

H1 Estimations under the hypothesis of S380 regression equation

\begin{tabular}{|c|c|c|c|c|c|c|c|c|c|}
\hline \multirow{2}{*}{$\begin{array}{l}\text { Years } \\
\text { Deciles }\end{array}$} & & 1995 & 1996 & 1997 & 1998 & 1999 & 2000 & 2001 & 2002 \\
\hline & D1 & 0.137 & 0.134 & 0.137 & 0.137 & 0.139 & 0.137 & 0.128 & 0.126 \\
\hline & D2 & 0.117 & 0.117 & 0.117 & 0.115 & 0.117 & 0.112 & 0.110 & 0.109 \\
\hline & D3 & 0.106 & 0.109 & 0.110 & 0.108 & 0.110 & 0.105 & 0.100 & 0.100 \\
\hline & D4 & 0.103 & 0.103 & 0.104 & 0.103 & 0.103 & 0.098 & 0.096 & 0.097 \\
\hline & D5 & 0.097 & 0.096 & 0.098 & 0.096 & 0.097 & 0.096 & 0.096 & 0.100 \\
\hline & D6 & 0.094 & 0.093 & 0.092 & 0.094 & 0.094 & 0.091 & 0.092 & 0.092 \\
\hline & D7 & 0.089 & 0.090 & 0.089 & 0.090 & 0.089 & 0.093 & 0.092 & 0.094 \\
\hline & D8 & 0.087 & 0.087 & 0.087 & 0.089 & 0.087 & 0.091 & 0.096 & 0.095 \\
\hline & D9 & 0.085 & 0.086 & 0.083 & 0.086 & 0.085 & 0.089 & 0.095 & 0.094 \\
\hline & D10 & 0.085 & 0.084 & 0.082 & 0.084 & 0.080 & 0.088 & 0.095 & 0.093 \\
\hline & & 1.000 & 1.000 & 1.000 & 1.000 & 1.000 & 1.000 & 1.000 & 1.000 \\
\hline
\end{tabular}

$\mathrm{H} 2$ Estimations under the hypothesis of S288 regression equation amended by adding the regression equation of probability (S228 in S380)

\begin{tabular}{|c|c|c|c|c|c|c|c|c|c|}
\hline \multirow{2}{*}{$\frac{\text { Years }}{\text { Deciles }}$} & & 1995 & 1996 & 1997 & 1998 & 1999 & 2000 & 2001 & 2002 \\
\hline & D1 & 0.150 & 0.147 & 0.152 & 0.153 & 0.156 & 0.154 & 0.146 & 0.143 \\
\hline & D2 & 0.128 & 0.128 & 0.129 & 0.127 & 0.129 & 0.124 & 0.123 & 0.122 \\
\hline & D3 & 0.113 & 0.116 & 0.118 & 0.116 & 0.118 & 0.113 & 0.109 & 0.109 \\
\hline & D4 & 0.107 & 0.107 & 0.108 & 0.107 & 0.107 & 0.102 & 0.101 & 0.101 \\
\hline & D5 & 0.097 & 0.096 & 0.098 & 0.097 & 0.097 & 0.096 & 0.096 & 0.100 \\
\hline & D6 & 0.091 & 0.090 & 0.089 & 0.090 & 0.091 & 0.088 & 0.089 & 0.089 \\
\hline & D7 & 0.083 & 0.084 & 0.083 & 0.083 & 0.083 & 0.086 & 0.085 & 0.087 \\
\hline & D8 & 0.078 & 0.078 & 0.077 & 0.079 & 0.077 & 0.081 & 0.085 & 0.084 \\
\hline & D9 & 0.074 & 0.076 & 0.072 & 0.074 & 0.073 & 0.077 & 0.081 & 0.081 \\
\hline & D10 & 0.079 & 0.078 & 0.074 & 0.075 & 0.070 & 0.078 & 0.085 & 0.084 \\
\hline & & 1.000 & 1.000 & 1.000 & 1.000 & 1.000 & 1.000 & 1.000 & 1.000 \\
\hline
\end{tabular}

H3 Estimations under the hypothesis of a generalized informal economy (based on the equation of regression used in the case of sample S228)

\begin{tabular}{|c|c|c|c|c|c|c|c|c|c|}
\hline \multirow{2}{*}{$\frac{\text { Years }}{\text { Deciles }}$} & & 1995 & 1996 & 1997 & 1998 & 1999 & 2000 & 2001 & 2002 \\
\hline & D1 & 0.122 & 0.119 & 0.124 & 0.124 & 0.127 & 0.124 & 0.117 & 0.114 \\
\hline & D2 & 0.108 & 0.108 & 0.110 & 0.107 & 0.110 & 0.105 & 0.103 & 0.102 \\
\hline & D3 & 0.101 & 0.103 & 0.105 & 0.103 & 0.105 & 0.100 & 0.096 & 0.096 \\
\hline & D4 & 0.099 & 0.100 & 0.101 & 0.099 & 0.100 & 0.095 & 0.093 & 0.094 \\
\hline & D5 & 0.095 & 0.094 & 0.097 & 0.095 & 0.096 & 0.094 & 0.094 & 0.098 \\
\hline & D6 & 0.094 & 0.094 & 0.093 & 0.094 & 0.095 & 0.091 & 0.092 & 0.091 \\
\hline & D7 & 0.091 & 0.092 & 0.091 & 0.092 & 0.092 & 0.095 & 0.093 & 0.095 \\
\hline & D8 & 0.091 & 0.092 & 0.091 & 0.093 & 0.091 & 0.095 & 0.099 & 0.098 \\
\hline & D9 & 0.092 & 0.095 & 0.090 & 0.092 & 0.092 & 0.096 & 0.101 & 0.101 \\
\hline & D10 & 0.106 & 0.104 & 0.100 & 0.101 & 0.094 & 0.105 & 0.113 & 0.112 \\
\hline & & 1.000 & 1.000 & 1.000 & 1.000 & 1.000 & 1.000 & 1.000 & 1.000 \\
\hline
\end{tabular}

